\title{
PENDAMPINGAN DESAIN KEMASAN WAJIK TAPAI MELAYU RIAU UNTUK MENINGKATKAN PENDAPATAN
}

\author{
Sri Maryanti ${ }^{1}$, Nining Sudiar ${ }^{2}$, Afred Suci ${ }^{1}$, Hardi $^{1}$ \\ 1Fakultas Ekonomi Universitas Lancang Kuning \\ 2Fakultas Ilmu Budaya Universitas Lancang Kuning \\ ssrimaryanti@yahoo.com
}

\begin{abstract}
This goal is to re-design the packaging for wajik tapai melayu that keeps up with the times without changing the logo and product names previously known, re-designing the packaging for wajik tapai melayu with more practical steps and calculating the performance of products and packaging for wajik tapai melayu. The method used is to coordinate with partners, assistance by providing views to partners about the re-design of the packaging for wajik tapai melayu and conducting market trials with new packaging from wajik tapai melayu by observing consumer responses related to changes in wajik tapai melayu packaging by going down to the shop where the product is marketed. The results show that 24 months before community service activities began, the average sales of new wajik tapai melayu were around Rp. 67 million per month after the partner's average income was Rp. 114 million per month or an increase of $69.4 \%$. Then the increase in income resulted from an increase of $16.3 \%$ on average to IDR 132 million per month. From the p-value of $.000 * * *$ it can be ignored that the average increase that occurs is significant. That is, offering care and rejuvenation packaging that can significantly increase income for community service partners. The packaging comparison test results show that consumers agree to this contract and significant graphic design and packaging form changes. Meanwhile, there was relatively no significant difference in terms of information on the packaging (p-value $=.159$ ) between the old packaging and the new package. This is because there is not much information added or given from the two packages, so that the type of information presented is relatively the same by consumers.
\end{abstract}

Keywords: Packaging Re-Design, Effectiveness of product and packaging treatment, Income

\begin{abstract}
Abstrak
Tujuan ini untuk melakukan re-desain kemasan wajik tapai melayu yang mengikuti perkembangan zaman tanpa mengubah logo dan nama produk yang terlebih dahulu dikenal, melakukan re-desain kemasan wajik tapai melayu dengan tahapan yang lebih praktis dan melakukan perhitungan kinerja produk dan kemasan wajik tapai melayu. Metode yang digunakan adalah melakukan koordinasi dengan mitra , pendampingan dengan memberikan padangan kepada mitra tentang re-desain kemasan wajik tapai melayu dan melakukan uji coba di pasaran dengan kemasan baru dari wajik tapai melayu dengan melihat respon konsumen terkait perubahan kemasan wajik tapai melayu dengan cara turun ke toko dimana produk dipasarkan. Hasilnya menunjukkan bahwa 24 bulan sebelum kegiatan pengabdian kepada masyarakat dimulai, rata-rata penjualan Wajik Tapai Melayu baru berkisar Rp 67 jutaan perbulan setelah kegiatan rata-rata pendapatan mitra menjadi Rp 114 jutaan perbulan atau meningkat sebanyak 69,4\%. Lalu pengamatan dilanjutkan dengan hasil terjadi peningkatan sebesar 16,3\% rata-rata pendapatan meningkat menjadi Rp 132 jutaan perbulan. Dari nilai p-value .000*** dapat disimpulkan bahwa rata-rata peningkatan yang terjadi adalah signifikan. Artinya, pemberian treatment dan peremajaan kemasan mampu secara nyata mendorong terjadinya peningkatan pendapatan bagi mitra pengabdian kepada masyarakat. Hasil uji komparasi kemasan menunjukkan konsumen menyepakati dilakukannya peremajaan kemasan ini dan menyukai perubahan signifikan pada desain grafis dan bentuk kemasan. Sementara itu dalam hal informasi di kemasan, relatif tidak terjadi perbedaan signifikan (p-value $=.159$ ) antara kemasan lama dengan kemasan baru. Hal ini disebabkan karena memang tidak banyak dilakukan penambahan atau pengurangan informasi dari kedua kemasan tersebut, sehingga jenis informasi yang disajikan relatif dipersepsikan sama oleh konsumen.
\end{abstract}

Kata kunci: Re-Desain Kemasan, Efektivitas treatment produk dan kemasan,Pendapatan

MARTABE : Jurnal Pengabdian Masyarakat|191 


\section{PENDAHULUAN}

\section{Analisa Situasi}

Usaha Wajik Tapai Melayu yang menjual produk makanan khass dari daerah Riau yang berbahan dasar tapai yang mana wilayah Siak Hulu merupakan penghasil ubi kayu. Peluang ini yang dimanfaatkan oleh mitra Wajik Tapai Melayu dengan nama usaha Puspa Melayu. Produk yang dihasilkan telah dipasarkan keberbagai wilayah baik didalam propinsi Riau maupun keluar Propinsi Riau. Wajik Tapai Melayu merupakan produk unggulan daerah Propinsi Riau yang tertuang didalam Renstra Provinsi Riau, produk ini termasuk kategori One Village One Product (OVOP) “ satu desa satu produk" . Hal ini diperkuat dengan Peraturan Mentri Dalam Negeri nomor 9 Tahun 2014 tentang Pedoman Pengembangan Produk Unggulan Daerah yaitu : (Sudiar, 2019)

a) Mempunyai daya saing yang tinggi di pasaran ( keunikan/ ciri spesifik, kualitas bagus , harga murah)

(b) Memanfaatkan potensi sumberdaya lokal yang potensial untuk dikembangkan

(c) Mempunyai nilai tambah yang tinggi bagi masyarkat pedesaan

(d) Secara ekonomi menguntung kan dan bermanfaat untuk meningkatkan pendapatan dan kemampuan sumberdaya manusia

(e) Layak didukung oleh bantuan modal dan kredit

Jika dilihat produk Wajik Tapai Melayu sangat potensial sekali untuk dikembangkan karena dapat dijakan icon produk dari Riau seperti halnya makan ringan dari Sumatera Barat keiripik sanjai, dimana setiap wisatawan yang berkunjungan ingin sekali membawa makanan khass dari daerah setempat. Sejak tahun 2008 usaha wajik tapai melayu ini didirikan telah melalui beberapa perubahan dalam kemasan produk hal ini didasarkan dari selera si pemilik sendiri seperti yang terlihat pada gambar 1 dan 2 dibawah ini. Jika diperhatikan kemasan tersebut tidak menjadi permasalahan hanya berbeda dalam bentuk tampilan saja.

$$
\text { Namun yang menjadi }
$$

permasalahan adalah jika seorang konsumen ingin mengkonsumsi produk wajik tapai melayu ini maka konsumen harus membuka kemasan sampai 5 (lima) tahapan untuk bisa sampai ke produknya. Untuk mengemas produk dibagian dalam digunakan kertas minyak yang kemudian dilapisi dengan plastic biasa dan terakhir dimasukkan kedalam plastic mika seperti yang ada digambar 3. Oleh karena itu perlu dilakukan pendampingan yang ebih serius kepada mitrawajik tapai melayu dalam hal ini Puspa Melayu agar kemasan produk tersebut memiliki tampilan yang efisien pada saat dikonsumsi.
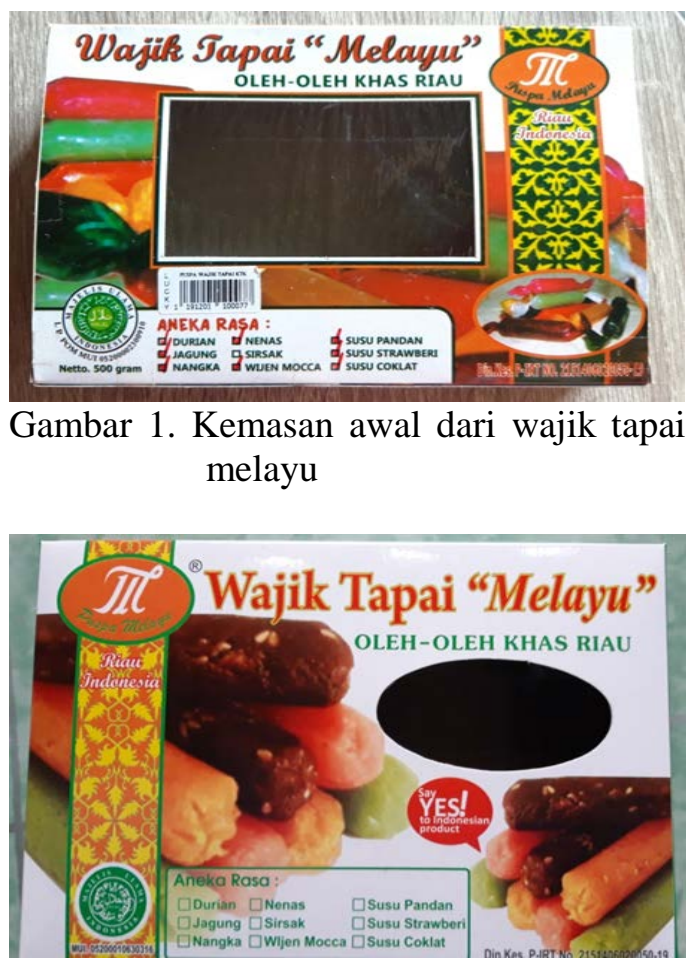

Gambar 2. Kemasan kedua dari wajik tapai melayu 
Sri Maryanti, dkk. Pendampingan Desain Kemasan Wajik Tapai Melayu Riau Untuk...
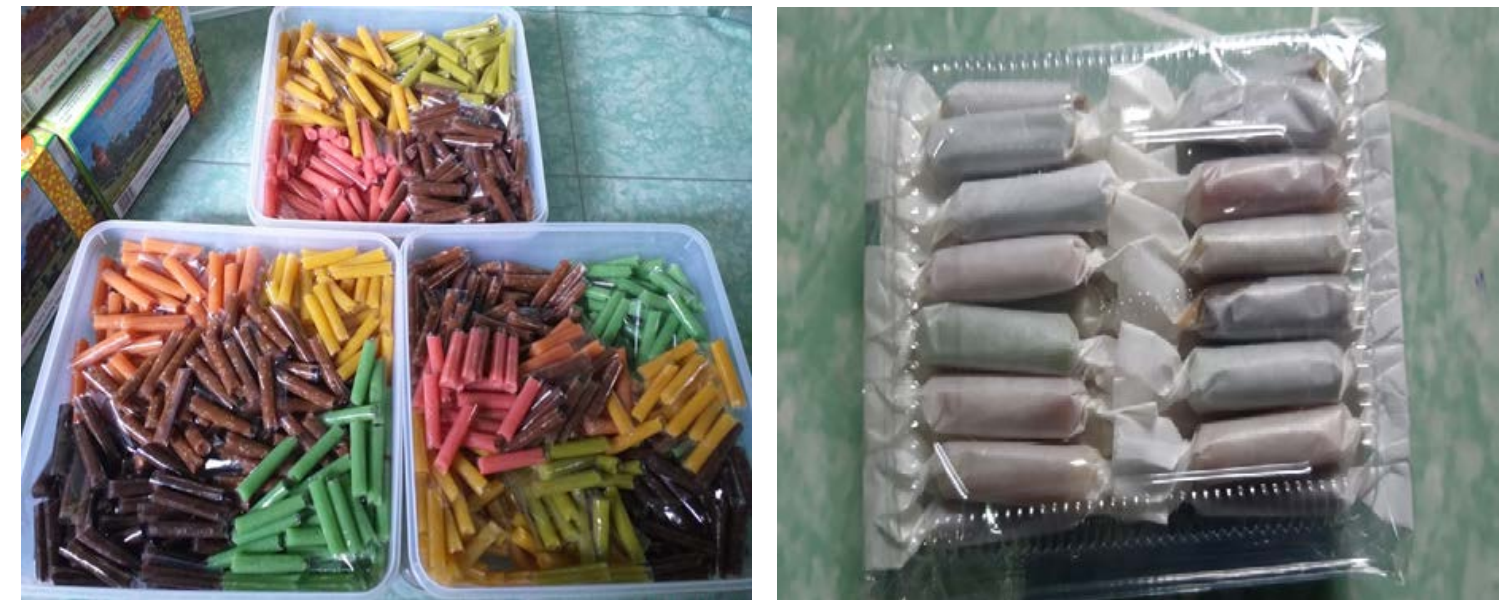

Gambar 3. Bentuk kemasan dalam wajik tapai melayu

Sebuah produk yang dijual memiliki nilai lebih jika dapat dikemas dengan sangat baik, namun tidak sedikit dari mitrayang mengabaikannya, hal ini cukup berdasar jika dibandingkan dengan pendapatan yang mereka peroleh, karena bagi mitramengubah desain kemasan akan menimbulkan biaya baru dan kurang yakinnya mitraterkait perubahan desain kemasan akan mampu menunjang pendapatan usaha mereka. Oleh karena itu pendampingan bagi mitrasangatlah penting karena mampu menguatkan usaha mitra dimana program pendampingan mampu memberikan dampak terhadap oengembangan usaha mitra terutama jika diamati dari indikator peningkatan omset dan pendapatan mitra.(Zuhroh et al., 2014)

Menurut (Setyariningsih \& Hidayat, 2019) bahwa Packing merupakan proses yang berkaitan dengan perancangan dan pembuatan wadah (container) atau pembungkus (wrapper). Kemasan harus dibuat semenarik mungkin sebagai pembeda dari produk yang lain. Kemasan merupakan penanda bagi konsumen akan sebuah produk, terkadang konsumen sulit mengingat nama sebuah produk maka melalui kemasan konsumen juga bisa mengingat produk tersebut.

Untuk memajukan sebuah usaha apalagi yang berskala kecil memang dibutuhkan pendampingan dalam hal ini fihak akademisi yang bisa ikut andil dalam pendampingan ini melalui kegiatan pengabdiankepada masyarakat, dimana pendamping bertugas melakukan aktifitas sebagai penghubung masyarakat dengan berbagai lembaga terkait, dimana pendamping memiliki kedudukan sebagai mitra pemerintah dan mitra masyarakat sehingga dituntut menjembatani berbagai kepentingan yang dating dari pemerintah maupun dari masyarakat (Rahmawati \& Kisworo, 2017).

\section{Permasalahan Mitra}

Adapun permasalahan mitra adalah:

1. Kemasan Produk yang tidak mengikuti perkembangan zaman

2. Desain Kemasan yang membutuhkan tahapan panjang untuk bisa mengkonsumsi produk wajik tapai melayu

3. Seberapa besar efektivitas kinerja produk dan kemasan wajik tapai melayu 


\section{Solusi Yang Ditawarkan}

Adapun solusi yang ditawarkan ke mitra dalam kegiatan pengabdian kepada masyarakat ini adalah

1. Melakukan re-desain kemasan wajik yang mengikuti perkemangan zaman tanpa mengubah logo dan nama produk yang terlebih dahulu dikenal

2. Melakukan re-desain kemasan wajik tapai melayu dengan tahapan yang lebih praktis

3. Melakukan perhitungan kinerja produk dan kemasan wajik tapai melayu

\section{METODE}

Metode yang digunakan dalam kegiatan pengabdian kepada masyarkat ini yaitu:

1. Melakukan koordinasi dengan mitra

Koordinasi ini bertujuan menyelaraskan jadwal tim pengabdian kepada masyarakat dengan mitra, mengingat kesibukkan mitra dengan usahanya.

\section{Memberikan pendampingan kepada mitra}

Kegiatan yang dilakukan saat pendmapingan ini adalah memberikan padangan kepada mitra tentang redesain kemasan wajik tapai melayu. Karena tidak semua mitra mau untuk mengubah desain kemasan produk mereka karena kehawatiran kalau produk mereka justru tidak laku di pasaran karena mitra befikir konsumen tidak akan mengenal produk mitra tersebut. Sehingga saat pendampingan tim Pengabdian Kepada Masyarakat membawa mitra lain yang telah lebih dahulu kami bantu dari sisi kemasan hanya untuk meyakinkan mitra wajik tapai melayu tentang perubahan bentuk kemasan.

\section{Melakukan uji coba di pasaran dengan kemasan baru dari wajik tapai melayu.}

Dalam hal ini tim pengabdian kepada masyarakat langsung turun ke toko-toko dimana produk wajik tapai melayu dipasarkan, disini tim melakukan pencatatan dan wawancara dengan pemilik toko tentang penjualan dari produk wajik tapai melayu . Dari hasil wawancara ini tim akan membuat analisis perhitungan penjualan saat menggunakan kemasan baru dan saat menggunakan kemasan lama dengan tujuan bisa meyakinkan mitra terkait respon pasar terhadap kemasn baru dari wajik tapai melayu.

\section{HASIL DAN PEMBAHASAN}

Hasil Pengujian Efektivitas Treatment Pada Produk dan Kemasan Wajik Tapai Melayu

Kegiatan pengabdian kepada masyarakat yang dilakukan kepada produk mitra pada dasarnya adalah untuk meningkatkan kinerja produk dan penerimaan konsumen pada sejumlah aspek produk tersebut. Selain melakukan pembenahan pada layout produksi, kegiatan pengabdian kepada masyarakat ini juga memberikan treatment-treatment tertentu dalam rangka peningkatan kualitas produk dan daya tarik kemasan produk. Dalam rangka menguji efektivitas pemberian treatment tersebut maka perlu dilakukan proses pengujian statistik untuk mengetahui seberapa signifikan terjadi perubahan dalam hal kinerja produk dan penerimaan konsumen terhadap produk mitra.

\section{A. Pengujian Efektivitas Treatment Terhadap Kinerja Produk \\ Proses evaluasi dilakukan dengan mengukur perubahan yang terjadi secara longitudinal. Pengamatan}


Sri Maryanti, dkk. Pendampingan Desain Kemasan Wajik Tapai Melayu Riau Untuk...

dokumen penjualan mitra dilakukan selama 41 bulan yang terbagi menjadi 24 bulan sebelum dilakukan treatment atau sebelum kegiatan pengabdian kepada masyarakat dimulai, 16 bulan setelah dilakukan treatment (perbaikan layout dan proses produksi) namun masih menggunakan kemasan lama (per 1 Maret 2019 hingga 30 Juni 2020), dan 1 bulan treatment dengan menggunakan kemasan baru (per 1 Juli hingga 1 Agustus 2020). Objek yang menjadi pengamatan adalah rata-rata pendapatan bulanan, rata-rata volume produksi perbulan, dan rata-rata jumlah produk diretur oleh penyalur mitra. Hasil pengujian statistik dapat dilihat pada tabel berikut:

Tabel 1. Perubahan kinerja produk Wajik Tapai Melayu

\begin{tabular}{|c|c|c|c|c|c|c|}
\hline \multirow{3}{*}{ Periode Pengamatan } & \multicolumn{6}{|c|}{ Kinerja Produk } \\
\hline & \multicolumn{2}{|c|}{$\begin{array}{l}\text { Rata-rata pendapatan } \\
\text { perbulan }\end{array}$} & \multicolumn{2}{|c|}{$\begin{array}{l}\text { Rata-rata volume } \\
\text { produksi perbulan } \\
\text { (kemasan) }\end{array}$} & \multicolumn{2}{|c|}{$\begin{array}{l}\text { Rata-rata produk } \\
\text { retur perbulan } \\
\text { (kemasan) }\end{array}$} \\
\hline & Nominal (Rp) & $\%$ & Box & $\%$ & Box & $\%$ \\
\hline Pra-treatment & 67.319 .229 & - & 2292 & - & 461 & - \\
\hline $\begin{array}{l}\text { Treatment tahun } 1 \\
\text { (kemasan lama) }\end{array}$ & 114.056 .000 & $\uparrow 69,4$ & 3564 & $\uparrow 55,5$ & 269 & $\downarrow 41,6$ \\
\hline \multirow[t]{2}{*}{$\begin{array}{l}\text { Treatment tahun } 2 \\
\text { (kemasan baru) }\end{array}$} & 132.640 .000 & $\uparrow 16,3$ & 4145 & $\uparrow 16,3$ & 196 & $\downarrow 27,1$ \\
\hline & \multicolumn{2}{|c|}{$\begin{array}{l}F=78.953 ; \\
p \text {-value }=.000^{* * *}\end{array}$} & \multicolumn{2}{|c|}{$\begin{array}{l}F=75.118 \\
p \text {-value }=.000^{* * *}\end{array}$} & \multicolumn{2}{|c|}{$\begin{array}{l}F=16.974 \\
p \text {-value }=.000^{* * *}\end{array}$} \\
\hline \multicolumn{7}{|c|}{ 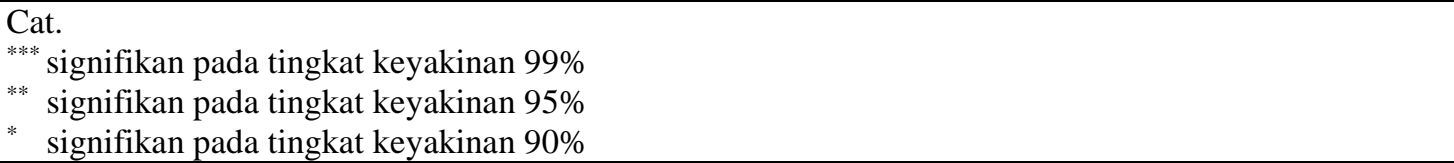 } \\
\hline
\end{tabular}

Tabel 1 menunjukkan bahwa 24 bulan sebelum kegiatan pengabdian kepada masyarakat dimulai, rata-rata penjualan Wajik Tapai Melayu baru berkisar Rp 67 jutaan perbulan. Setelah dilakukan kegiatan pengabdian keapada masyarakat, maka sejumlah treatment dilakukan, utamanya adalah mereorganisir layout produksi, modernisasi dan intervensi pada proses produksi. Hasilnya adalah, dalam periode treatment tahap 1 (tahun pertama), rata-rata pendapatan mitra menjadi Rp 114 jutaan perbulan atau meningkat sebanyak 69,4\%. Pada periode pengamatan di tahun kedua dimana sudah dilakukan peremajaan pada kemasan produk, terjadi peningkatan sebesar 16,3\% dimana ratarata pendapatan meningkat menjadi $\mathrm{Rp}$ 132 jutaan perbulan. Jika dilihat dari nilai p-value .000*** maka dapat disimpulkan bahwa rata-rata peningkatan yang terjadi adalah signifikan. Artinya, pemberian treatment dan peremajaan kemasan mampu secara nyata mendorong terjadinya peningkatan pendapatan bagi mitra pengabdian kepada masyarakat.

Sementara itu dalam hal volume produksi, sebelum dilakukan treatment, rata-rata volume produksi mitra hanya berkisar 2.292 boks perbulan. Setelah dilakukan inovasi produksi terjadi peningkatan sebesar 55,5\% atau menjadi rata-rata 3.564 boks perbulan. Kemudian pada kegiatan P3UD tahun kedua dilakukan peremajaan kemasan yang berdampak pada meningkatnya volume produksi menjadi rata-rata 4.145 boks perbulan atau terjadi pertumbuhan sebesar 16,3\%. 
Sebelum dilakukan treatment atau sebelum kegiatan pengabdian kepada masyarakat dimulai, besarnya retur produk oleh para penyalur mitra menjadi permasalahan utama yang menyebabkan laba mitra menjadi tidak optimal. Produk-produk yang dikembalikan oleh para penyalur tersebut menjadi limbah yang tidak dapat dijual ataupun direproduksi. Ratarata jumlah produk retur adalah 461 boks setiap bulannya. Setelah diberikan treatment pada tahun pertama, terjadi penurunan produk retur secara signifikan yaitu $41,6 \%$ atau menjadi 269 boks perbulan. Kemudian setelah dilakukan peremajaan kemasan pada tahun kedua, penurunan kembali terjadi sebesar 196 boks perbulan atau menurun sebanyak 27,1\%.

\section{B. Pengujian Penilaian Konsumen Pada Peremajaan Kemasan Produk}

Selain kinerja produk mitra itu sendiri, penilaian konsumen pada peremajaan kemasan produk juga menjadi perhatian tim P3UD. Kemasan adalah aspek pertama kali dilihat dan dinilai oleh konsumen sebelum memutuskan membeli atau tidak membeli. Peremajaan kemasan dilakukan cukup drastis yakni dari semula berbentuk persegi panjang dengan dimensi yang horisontal, menjadi berbentuk tabung vertikal keatas. Perubahan dilakukan pada aspek desain grafis, meliputi pewarnaan, bentuk, informasi, dan daya tarik kemasan secara keseluruhan.

Untuk melakukan pengujian efektivitas peremajaan kemasan produk Wajik Tapai Melayu ini, maka dilakukan survey terhadap 50 orang konsumen. Sampel dilakukan dengan teknik convenience dilokasi penyalur produk mitra. Kepada para responden tersebut, diperlihatkan dua bentuk kemasan secara bersamaan. Kemasan A adalah kemasan lama, sedangkan kemasan B merupakan tipe hasil peremajaan. Setelah responden mengamati kedua kemasan tersebut selama \pm 5 menit, masing-masing kemudian diberikan kuesioner untuk diisi. Rekapitulasi kuesioner ini kemudian diuji dengan menggunakan pengujian komparasi Paired-sample Test dengan hasil sebagaimana Tabel 2.

Tabel 2. Hasil Uji Komparasi Kemasan

\begin{tabular}{|l|c|c|c|}
\hline \multicolumn{1}{|c|}{ Pasangan Sampel } & $\boldsymbol{M}$ & $\boldsymbol{S D}$ & p-value \\
\hline Warna kemasan A & 2.64 & .94 & $.000^{* * *}$ \\
Warna kemasan B & 3.90 & .76 & \multirow{2}{*}{$.000^{* * *}$} \\
\hline Bentuk kemasan A & 2.84 & .82 & \multirow{2}{*}{.159} \\
Bentuk kemasan B & 3.58 & .81 & $.000^{* * *}$ \\
\hline Informasi kemasan A & 3.70 & .76 & \\
Informasi kemasan B & 3.74 & .78 & \\
\hline Daya Tarik kemasan A & 2.96 & .78 & \\
Daya Tarik kemasan B & 3.98 & & \\
\hline Cat. & & \\
${ }^{* * *}$ signifikan pada tingkat keyakinan 99\% & & \\
${ }^{* * *}$ signifikan pada tingkat keyakinan 95\% & & \\
${ }^{*}$ signifikan pada tingkat keyakinan 90\% &
\end{tabular}


Sri Maryanti, dkk. Pendampingan Desain Kemasan Wajik Tapai Melayu Riau Untuk...
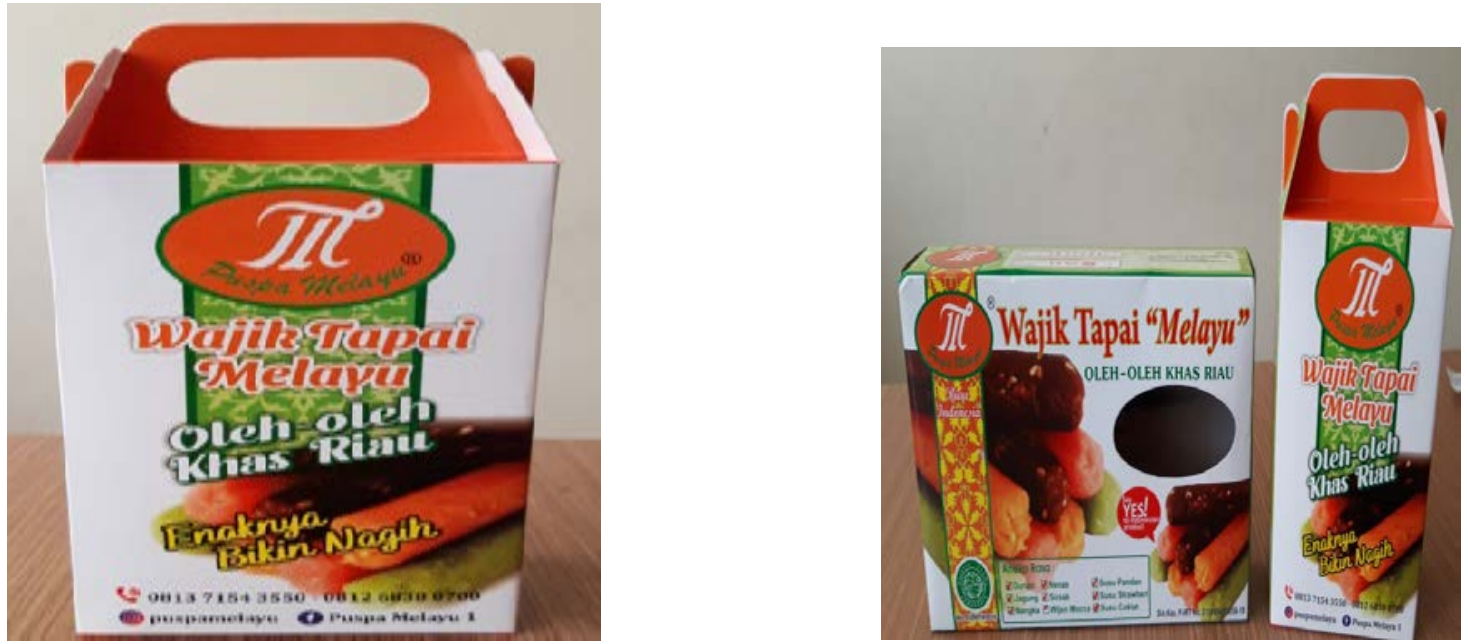

Gambar 4. Perbandingan kemasan lama dengan desain kemasan baru

\section{SIMPULAN}

Kegiatan pengabdian kepada masyarakat ini berjalan dengan baik, respon dari mitra wajik tapai melayu sangat postif terlihat dari selama tiga tahun kegiatan ini dijalankan melalui SKIM PPPUD dari Kemenristek DIKTI dengan lancar. Tanggapan dari mitra wajik tapai melayu terkait re-desain kemasan sangat disambut baik karena dengan melakukan re-desain kemasan wajik tapai berdampak terhadap pendapatan mitra. Disamping itu respon konsumen juga sangat positif dimana konsumen menyukai dengan adanya redesain kemasan wajik tapai melayu ini. Diharapkan dengan adanya kegiatan ini mampu membantu mitra UMKM yang lain untuk dapat mengembangkan usaha mereka sehinga menjadi lebih baik.

\section{UCAPAN TERIMA KASIH}

Terimakasih kepada Direktorat Riset, Dan Pengabdian Masyarakat Direktorat Jenderal Penguatan Riset Dan Pengembangan Kementrian Riset dan Teknologi / Badan Riset dan Inovasi Nasional Sesuai Dengan Kontrak Pengabdian Kepada Masyarakat Nomor :
015/LL10/AM/2020 Melalui Program Produk Unggulan Daerah Pada Tahun 2020

\section{DAFTAR PUSTAKA}

Rahmawati, E., \& Kisworo, B. (2017). Peran Pendamping dalam Pemberdayaan Masyarakat Miskin melalui Program Keluarga Harapan. Journal of Nonformal Education and Community Empowerment. https://doi.org/10.15294/pls.v1i 2.16271

Setyariningsih, E., \& Hidayat, M. S. (2019). Pendampingan Pengemasan Produk ( Packing) dan Pembukuan Sederhana Untuk Meningkatkan Kemampuan UKM dalam Mengelola Usaha pada UKM Jamu Tradisional di Kota Mojokerto. ABDIMAS NUSANTARA: Jurnal Pengabdian Kepada Masyarakat.

Sudiar, N. (2019). Konsep OVOP Untuk Mengidentifikasi Produk Unggulan Daerah (Studi Kasus Wajik Tapai Melayu). Dinamisia: Jurnal 
MARTABE : Jurnal Pengabdian Masyarakat Vol 4 No 1 Tahun 2021 Hal 191-198

$\begin{array}{lr}\text { Pengabdian } & \text { Kepada } \\ \text { Masyarakat, } & 3 . \\ \text { https://doi.org/10.31849/dinam } & \\ \text { isia.v3i0.2864 } & \end{array}$

Zuhroh, I., Br, A., \& Kurniawati, E. T. (2014). Pendampingan

Pengembangan Usaha Warung Makan. Jurnal Dedikasi. 